\title{
Maksātnespēja un sabiedrības drošība: krimināltiesiskie aspekti
}

\author{
Dr. iur. Ivars Kronis \\ Rìgas Stradina universitāte, \\ Juridiskā fakultāte, Latvija \\ ivars.kronis@rsu.lv
}

\section{Kopsavilkums}

Laiks, kas ir pagājis kopš jaunā Maksātnespējas likuma stāšanās spēkā (šis likums ir mainījis maksātnespējas koncepciju un procedūru norises gaitu, tādējādi ietekmējis krimināltiesisko aizsardzību), nav pietiekams, lai būtu izveidojusies tiesu prakse šajā jomā. Zinātniskās literatūras avotu par maksātnespējas krimināltiesiskās aizsardzības regulējumu Krimināllikumā nav daudz. Tomēr Maksātnespējas likuma vairāk nekā piecu gadu darbïba ir piemērots brīdis maksātnespējas krimināltiesiskās aizsardzības problemātikas aktualizēšanai.

Atslēgvārdi: maksātnespēja, krimināltiesības, sabiedrības drošība.

\section{levads}

Mainīgas ekonomiskās situācijas apstākḷos valsts ne tikai veicina komercdarbību, bet arī nodrošina noteiktu kārtību ieinteresēto pušu aizsardzībai, ja juridiskas vai fiziskas personas vairs nespēj pildìt savas saistîbas. Rodoties un nostiprinoties maksātnespējas tiesībām, lielu nozīmi iegūst arī kriminālatbildỉba par ḷaunprātībām maksātnespējas procesā.

Ekonomiskie noziedzīgie nodarïjumi ir specifiska noziedzīgo nodarījumu grupa, kas skar tautsaimniecības intereses un ietekmē finansiāli saimnieciskās attiecības [5, 301]. Šajā grupā tiek iekḷauti arī ar maksātnespēju saistītie noziedzīgie nodarījumi.

Darba mērḳis. Raksta mērḳis ir, analizējot pret maksātnespēju vērsto nodarījumu īpatnības, izvērtēt tiesisko normu dažādos piemērošanas aspektus. Ierobežotā apjoma dēl rakstā uzmanība nav veltìta kredītiestāžu un citu finanšu un kapitāla tirgus dalībnieku maksātnespējas krimināltiesiskajiem aspektiem. 
Materiāls un metodes. Pētījuma empīrisko bāzi veido zinātnieku darbi un rakstu krājumu materiāli, publikācijas periodiskajos izdevumos un pirmavoti, tiesību akti, statistikas dati, interneta resursi, kā arì cita publiski pieejamā informācija. Pètījuma izstrādē izmantota analīiskā, salīdzinošā, induktīvā un deduktīvā pētniecỉbas metode.

\section{Rezultāti un diskusija}

Maksātnespējas tiesības ir sens tiesību institūts, kas sevī ietver kā materiālās, tā arī procesuālās tiesību normas. Šo tiesību aizsākumi meklējami seno kultūru valstīs ar augstu saimniecisko un kredīta attiecību līmeni [3]. Ziņas par maksātnespējas tiesisko regulējumu var atrast jau senās Grieḳijas, Ėğiptes, kā arī Romas tiesībās [20, 285]. Gadsimtu gaitā šo tiesību saturs ir būtiski mainījies. Piemēram, romiešu tiesībās sākotnēji maksātnespēju regulēja seno tiesību piemineklis - XII tabulu likumi, kas neapmierinātajiem kreditoriem deva tiesības piepildìt savas naida jūtas pret parādnieku, sacērtot to gabalos. Bet turpmākajā šo tiesību attīstības posmā neapmierināto kreditoru tiesības tika ierobežotas ar iespējām pārdot maksātnespējīgo parādnieku verdzībā. Tikai 326. gadā pien̦emtajā likumā "Lex potelia" tika noteikts, ka maksātnespējīgo parādnieku drīkst pārdot verdzībā tikai tad, ja maksātnespēja iestājusies viṇa noziedzīgo darbību rezultātā.

Mūsdienās maksātnespējas tiesības ir izveidojušās par visai sarežgìitu institūtu, un, kā norāda Jānis Jurkāns, šo tiesību regulējošie likumi ieņem būtisku vietu ekonomiski attīstīto valstu tiesību sistēmā. To nosaka šo likumu pamatfunkcija, t. i., attiecību stabilizācija komercdarbībā un riska pakāpes samazināšana šajās attiecībās. Saimnieciskās darbības regulēšanai domātais tiesību normu komplekss, kas aptver gan civiltiesību, gan administratīvo tiesību, nereti arī krimināltiesību normas, kā norāda Kaspars Balodis, tiek sauktas par saimnieciskajām tiesībām, pie kurām pieskaita arī maksātnespējas tiesības $[1,49]$. Maksātnespējas tiesības ir viena no Latvijas tiesību sistēmas nozarēm. Pati par sevi tā ir tiesību normu sistēma, juridisko normu kopums, kas reglamentē finansiālās grūtībās nonākuša parādnieka saistību izpildi un, ja iespējams, maksātspējas atjaunošanu tiesiskās aizsardzības un maksātnespējas procesā.

Kaut gan kopš 2010. gada 1. novembra ir spēkā jauns Maksātnespējas likums, tomēr joprojām tiek piemērotas arī 2007. gada Maksātnespējas likuma un 1996. gada likuma "Par uzṇēmumu un uzṇēmējsabiedrību maksātnespēju" normas. Šāda prakse neveicina ne tikai civiltiesiskās apgrozības stabilitāti, bet arī rada neskaidrību krimināltiesiskajā aspektā, jo katru reizi, mainot tiesisko regulējumu, būtiski tiek grozìts pats maksātnespējas process. Tāpēc līdztekus jāpiemēro dažādas tiesību normas ar atškíirīgu regulējumu vienādiem gadījumiem. Juridiskajā literatūrā tiek minēts, ka likuma efektivitāti nosaka ne tikai tiesību normu formulējumu precizitāte [19, 281], bet arī tā kvalitāte. Biežas maksātnespēju regulējošo tiesību normu izmaiṇas arī nerada stabilu un drošu vidi. 
Raugoties no vēsturiskā viedokḷa [9], centieni sakārtot šo jomu bijuši jau krietni sen. 1933. gada Sodu likumā atbildība par noziedzīgiem nodarījumiem [11; 12], kas atbilst Krimināllikuma XIX nodaḷai "Noziedzīgi nodarïjumi tautsaimniecībā", bija paredzēta dažādās nodaḷās, un maksātnespējas regulējums tika ietverts XXXVIII nodaḷā "Bankrots, augḷošana un citāda sodāma l̦aunprātība attiecībā uz mantu" [4, 418]. Analizējot maksātnespējas institūta vēsturisko attīstìbu, Jānis Bērziņš norāda [2], ka pirms Otrā pasaules kara krimināltiesībās lielāka uzmanība tika pievērsta noziedzīgiem nodarỉjumiem, kas izpaudās apzinātā maksātnespējas un bankrota stāvokḷa izraisīšanā, tikai netieši pievēršoties noziedzīgiem nodarỉjumiem, kas attiecas uz pašu maksātnespējas procesu.

Savukārt padomju krimināltiesībās ar maksātnespēju saistīti noziedzīgi nodarījumi nepastāvēja $[15,311 ; 16,207]$, jo tiesībās nebija sastopams pats maksātnespējas institūts.

Tas tika atjaunots pēc neatkarības atgūšanas Latvijas tiesiskās sistēmas transformācijas laikā $[10,277]$. Pirmie likumi šajā jomā bija "Par uzṇēmumu un uzn̦ēmējsabiedrību maksātnespēju un bankrotu" un "Par uzṇēmumu un uzṇēmējsabiedrību maksātnespēju", bet, kā norāda Edgars Stafeckis [18, 281], jau tolaik likumdevējam bija skaidrs, ka esošās bankrota tiesību normas neatbilst tiesību sistēmai un ir pretrunā ar Latvijā jau ieviestajiem vai plānotajiem tiesību institūtiem. Šie normatīvie akti kā maksātnespējas risinājumu paredzēja mierizlīgumu, sanāciju un bankrotu. Turklāt tie attiecās tikai uz juridiskām personām.

Savukārt Latvijas Kriminālkodeksā (LKK), kas bija spēkā līdz 1999. gada 31. martam, kriminālatbildība maksātnespējas jomā bija noteikta sestās "A" nodaḷas "Noziegumi uzñēmējdarbībā" trīs pantos:

1) Uzṇēmuma (uzṇēmējsabiedrības) novešana līdz maksātnespējai vai bankrotam (LKK 161.7 p.);

2) Maksātnespējas pieteikuma neiesniegšana vai nepatiesa pieteikuma iesniegšana (LKK $161 .{ }^{11} \mathrm{p}$.);

3) Maksātnespējas procesa pārkāpšana (LKK $161 .{ }^{12}$ p.).

2007. gadā pieṇemtais Maksātnespējas likums tika izstrādāts ekonomiskās izaugsmes laikā. Tajā iekḷautais regulējums sasaucās ar izaugsmes prognozēm un pārliecību par ekonomisko stabilitāti, un procedūras tika veidotas, palıajoties, ka masveida maksātnespējas vilnis nav sagaidāms [18, 281]. Savukārt 2010. gadā pieņemtais Maksātnespējas likums tika izstrādāts krīzes laikā. Tad izaugsmes atjaunošanai ḷoti aktuāla bija nepieciešamība iesaldētos aktīvus pēc iespējas ātrāk atgriezt komerctiesiskajā apritē, bet dzīvotnespējīgos parādniekus vajadzēja ātri un efektīvi izslēgt no komercvides [18, 281]. Tādējādi var secināt, ka likumdevējs tik neilgā laikā visai kardināli un atškirīigi noteica maksātnespējas regulējuma koncepciju, kas izraisīja arī atšķirīgu iesaistīto personu rīcību maksātnespējas jomā.

Turklāt sodu politiku Latvijā ietekmēja arī likumdevēja 2012. gada 13. decembra grozìjumi Krimināllikumā, kas stājās spēkā 2013. gada 1. aprīlì, un to mērḳis, mazinot brīvības atṇemšanas sodu termiṇus, nav panākt noziedzīgu nodarījumu klasifikācijas 
maiṇu, bet nodrošināt to, lai sods atbilstu noziedzīga nodarījuma bīstamībai un kaitīgumam, tika skartas arī visas normas attiecībā uz maksātnespēju.

Savukārt Saeimas izdarītie grozījumi tiesību aktos par maksātnespējas procesa administratoriem, pielīdzinot vinus valsts amatpersonām, tiek vērtēti pretrunīgi. Tādējādi likumdevējs maksātnespējas procesa administratoriem ir noteicis stingrāku atbildību, jo uz viniiem attiecas Krimināllikuma XXIV nodą̧ā "Noziedzīgi nodarỉjumi valsts institūciju dienestā" ietvertie noziedzīgie nodarījumi.

Maksātnespējas procesa administratori nepilda nevienu valsts pārvaldes funkciju, kā arī nerīkojas ar valsts mantu vai naudas līdzekḷiem, tāpēc to pielīdzināšana valsts amatpersonām ir nepamatota. Maksātnespējas procesa administratori ne pēc veikto darbību rakstura, ne amata būtības neatbilst valsts amatpersonas kritērijiem.

Analogiiski Eiropas Savienības tiesas 2015. gada 10. septembra spriedumā lietā C-151/14 Eiropas Komisija pret Latvijas Republiku tika secināts par notāra darbībām Latvijā: lai gan notārs izdod notariālos aktus, ved mantojuma lietas un škíi laulības, tomēr viṇa joma nav uzskatāma par tiešu un konkrētu dalību valsts varas ìstenošanā un tāpēc Latvijas pilsonības nosacījums notāriem nav attaisnojams. Tāpēc var secināt, ka Latvijas likumdevējs ne tikai attiecībā uz maksātnespējas procesa administratoriem, bet arī uz citām reglamentētām juristu profesijām rīkojas nepārdomāti.

Šāda likumdevēja rīcība ir tikusi ne tikai kritizēta [13; 14], bet arī vērtēta Latvijas Republikas Satversmes tiesas 2015. gada 21. decembra spriedumā lietā Nr. 2015-03-01, atzīstot, ka, ciktāl tā nenodrošina maksātnespējas procesa administratoriem, kuri vienlaikus ir arī zvērināti advokāti, profesionālās darbības garantijas izvēelētās nodarbošanās saglabāšanai, tā ir neatbilstoša Latvijas Republikas Satversmes 106. panta pirmajam teikumam, t. i.: "Ikvienam ir tiesības brīvi izvēlēties nodarbošanos un darbavietu atbilstoši savām spējām un kvalifikācijai." Satversmes tiesas ieskatā, valsts amatpersonai noteiktais pienākums deklarācijā ietvert normatīvajos aktos prasīto informāciju par noslēgtajiem uzṇēmuma un pilnvarojuma līgumiem un šo līgumu pusēm, kā arī ienākumiem un to gūšanas avotu var nonākt pretrunā ar advokāta darbības konfidencialitātes principu, jo tādējādi tiktu atklāta informācija par to, ka advokāts sniedzis juridisko palīdzību konkrētai personai.

Attiecībā uz tiem maksātnespējas procesa administratoriem, kuri nav zvērināti advokāti, Latvijas Republikas Satversmes tiesa lietā Nr. 2015-04-01 lēma izbeigt tiesvedību, radot vēl lielākas neskaidrības.

Kriminālatbildība par pārkāpumiem maksātnespējā noteikta Krimināllikuma XIX nodạ̦ā "Noziedzīgi nodarījumi tautsaimniecībā", kurā ietverti četri noziedzīgo nodarījumu veidi, proti, atbildība paredzēta:

1) par novešanu līdz maksātnespējai (KL 213. p.);

2) par nepatiesa maksātnespējas procesa pieteikuma iesniegšanu (KL 214. p.);

3) par maksātnespējas procesa kavēšanu (KL 215. p.);

4) par tiesiskās aizsardzības procesa noteikumu pārkāpšanu (KL 215. ${ }^{1}$ p.). 
Tomēr, no judikatūras viedokḷa vērtējot pieejamos Latvijas Republikas Augstākās tiesas Krimināllietu departamenta pēdējos desmit gados publicētos nozīmīgāko lēmumu krājumus, jāsecina, ka starp tiem atrodami vien trīs nolēmumi šajā jomā (divi no tiem attiecas uz maksātnespējas pieteikuma neiesniegšanu, kas nu jau ir dekriminalizēts nodarījums) $[6,317 ; 7,248 ; 8,158]$, kas neliecina par plašu tiesu praksi maksātnespējas lietās.

\section{Secinājumi}

Latvijas mūsdienu maksātnespējas krimināltiesisko aspektu apskats raisa cerību, ka kārtējos grozỉjumos un papildinājumos, ko veiks likumdevējs, tiks ietvertas ne tikai progresīvas idejas, bet tiks n̦emta vērā arī pēdējo gadu pieredze un tiesiskais regulējums kḷūs par drošu tiesību un interešu garantu.

\section{Insolvency and Public Safety: Criminal Law Aspects}

\section{Abstract}

The period since enactment of the new Insolvency Law that has changed the concept of insolvency as well as the course of procedure and, therefore, has affected the application of criminal legal protection has been too short for development of judiciary in this area. The few sources of scientific literature on the regulation of criminal legal protection of insolvency in the Criminal Law have been published before enactment of the new Insolvency Law. Five years of operation of the Insolvency Law is a milestone for updating the issues of criminal legal protection of insolvency and extended assessment of insolvency regulations in the Criminal Law.

Keywords: insolvency, criminal law, public safety.

\section{Literatūra}

1. Balodis, K. Ievads civiltiesībās, Rīga: Zvaigzne ABC, 2007.

2. Bērziņš, J. Maksātnespējas procesa krimināltiesiskie aspekti. Latvijas Vēstnesis. 9.10.2007., 41 (494).

3. Jurkāns, J. Kreditora intereses maksātnespējas procesā. Jurista Vārds, sākums - 26.09.2000., beigas - 10.10.2000.

4. Krastiņš, U., Liholaja, V., Niedre, A. Krimināltiesības. Sevišķā daḷa. Trešais papildinātais izdevums. Zin. red. prof. U. Krastiņš. Rīga: Tiesu namu aǵentūra, 2009.

5. Kriminoloǵija: mācību grāmata. Latvijas Neatkarīgo kriminologu asociācija, zin. red. K. Kipēna, A. Vilks. Papild. izd. Rīga: Nordik, 2004.

6. Latvijas Republikas Augstākās tiesas Senāta spriedumi un lēmumi 2013. Rīga: Tiesu namu aǵentūra, 2014. 
Ivars Kronis. Maksātnespēja un sabiedrības drošǐba:

krimināltiesiskie aspekti

7. Latvijas Republikas Augstākās tiesas Senāta Krimināllietu departamenta lēmumi 2008. Rīga: Tiesu namu aǵentūra, 2009.

8. Latvijas Republikas Augstākās tiesas Senāta Krimināllietu departamenta lēmumi 2006. Rīga: Tiesu namu aǵentūra, 2007.

9. Latvijas tiesību vēsture (2014-2000). Mācību grāmata juridiskajām augstskolām un fakultātēm. Prof. Dr. iur. Dītriha Andreja Lēbera red. Rīga: LU žurnāla "Latvijas Vēsture" fonds, 2000.

10. Meḷkisis, E. Kā panākt reālu krimināljustīcijas eiropeizāciju? No: Mel̦kisis, E. Latvijas tiesiskās sistēmas cel̦š uz demokrātisku tiesisku valsti. Rakstu kräjums. Rīga: Tiesu namu aǵentūra, 2014.

11. Mincs, P. Krimināltiesības. Sevišk,ā daḷa. Ar V. Liholajas komentāriem. Rīga: Tiesu namu aǵentūra, 2005.

12. Mincs, P. Krimināltiesību kurss. Vispārējā daḷa. Ar U. Krastiṇa komentāriem. Rīga: Tiesu namu aǵentūra, 2005.

13. Muciṇš, L. Valsts amatpersonas statuss maksātnespējas procesa administratoriem: problemātiskie aspekti. Jurista Vārds. 01.12.2015, 47 (899).

14. Novicāns, K. Maksātnespējas procesa administratora statusa reforma. Jurista Vārds. 30.09.2014, 38 (840).

15. Padomju tiesības. V. Millera un E. Mel̦kiša red. Rīga: Zvaigzne, 1978.

16. Plotnieks, A. Padomju Sociālistiskās tiesības. Rīga: Zvaigzne, 1975.

17. Plotnieks, A. Tiesību teorija E juridiskā metode. Rìga: N.I.M.S., 2013.

18. Stafeckis, E. Maksātnespējas tiesību attīstības ietekme uz komercvidi Latvijā. No: Komertiesību aktuālie jautājumi Latvijā un Eiropā: Komercdarījumi. Atbildība. Komercstrīdi. Rīga: Tiesu namu aǵentūra, 2013.

19. Šulmane, D. Tiesību normu efektivitātes jēdziena problemātika mūsdienu tiesību sociolog̣ijā. No: Juridiskās zinātnes aktuālās problēmas. Rakstu krājums. Rīga: Zvaigzne ABC, 2012.

20. Velyvis, S., Mikuckiene, V. Origin of bankruptcy procedure in Roman law. Jurisprudencia. 2009, 3 (117). 